\title{
THE ORGANIZATION OF A METROPOLITAN REGION
}

\author{
Victor Jones $\dagger$
}

\section{A Theory of Intergovernmental Relations}

William T. R. Fox, Director of the Institute of War and Peace Studies at Columbia University, and a close observer of local affairs, has on several occasions declared that the only theory that can describe intergovernmental relations in a metropolitan community is a theory of international politics. Certainly most metropolitan areas are locally governed by many local governments-each with jurisdiction over a fragment of the metropolitan area and each as jealous and distrustful of the others as if they were national states. Local governments in metropolitan areas are becoming increasingly interdependent in all aspects of community life except the governmental and the political.

In fact, a unit of local government is more secure in its organizational intergrity than are many national states. Everywhere in the United States either the law or the tradition of home rule has made municipal corporations and most other units of local government, except small special districts, almost as indestructible in fact as Texas home rule municipalitities are at law. ${ }^{1}$ This means that either single municipalities, however small they may be, or a small proportion of the total number of municipalities, possess an effective veto over the decision of a majority of the people in a metropolitan area to reorganize the local governments of the area into a metropolitan government. One example of this is the well-known practice of incorporating a municipality for the sole purpose of preventing the annexation of a fringe area to an adjacent municipality. A second may be found in the provisions of state constitutions such as that of Ohio, which requires, before any power vested in municipalities can be concurrently or exclusively exercised by the county, a favorable vote (1) in the county, (2) in the largest municipality, (3) in the county outside such municipality, and (4) in each of a majority of the municipalities and townships in the county.

$\dagger$ Professor of Political Science, University of California (Berkeley). A.B., 1932, Howard College; Ph.D., 1939, University of Chicago.

1. City of Houston v. Magnolia Park, 115 Tex. 101, 276 S.W. 685 (1925); see Keirh, City and County Home Rule in Texas (1951). 
If local governments in metropolitan areas act toward each other as if they were national states, we should not be surprised to recognize among proposals for reorganizing them counterparts of world government, world federation, functional organization and bilateral and multilateral compacts.

There is less talk today than before the war about the "integration" of local governments into a metropolitan government. The creation of a single local government for a metropolitan area by means of extensive annexations to the central city or of city-county consolidation has been replaced in post-war discussions by proposals to federate existing units of local government into a limited metropolitan government, or to consolidate particular functions or activities by transferring them to a more territorially extensive unit, by jointly administering them, or by creating special districts or authorities. ${ }^{2}$ The arguments for and against such proposals are strikingly similar to those used by the proponents and opponents of the United Nations, world federation, regional organizations or international functionalism. ${ }^{3}$

The analogy between metropolitan organization and international organization is suggestive, and can serve to remind us that we are dealing with units of local government that are tough organizations with many political and legal protections against annihilation or absorption by another government. Perhaps a study of the experiences of international organization would lead us to a metropolitan organization that would enable counties, townships and municipalities to function more satisfactorily. ${ }^{4}$

2. The Nashville and Davidson County planning commissions have recently proposed a single metropolitan government to replace the city and county governments. The reason they give for recommending a single unified metropolitan government is that the existing system, a federated municipality, the expansion of county functions in suburban areas, or the creation of special districts would tend "to divide the loyalties of community leadership and the authority of local government at times when unity of action is urgently needed." They point out, however, that "the federated municipality is probably most appropriate in those metropolitan areas (usually the larger and older ones) whose central cities are surrounded by a rigid network of separate suburban governments." Nashville and Davidson County Planning Commissions, Plan of Metropolitan Governarent for Nashville and Davidson County 9, 23 (1956).

3. See Claude, Swords Into Plowshares: The Problems and Progress of INTERNATIONAL Organization (1956). Jefferson B. Fordham must have been aware of the analogy when he discussed in a single series of lectures the problems of politically organizing the metropolis, the region and the world. FORDAAM, A LARGER CoNCEPT OF COMMUNITY (1956).

4. The reader can easily substitute the terms necessary to make the following statement by Claude applicable to the metropolitan problem: "International organization-which ought, strictly speaking, to be called interstate organization-is a phenomenon of the multi-state system. There are, in fact, four prerequisites for the development of international organization. The first two relate to the existence of objective facts or conditions: the world must be divided into a number of states which function as independent political units, and a substantial measure of contact must exist between these subdivisions. The other requirements are subjective in nature: the states must develop an awareness of the problems which arise out of their coexistence, and, on this basis, come to recognize the need for creation of institutional devices and syste- 
Two recent analysts have concluded that it is undesirable to press for the governmental reorganization of metropolitan areas into integrated general governments. Edward G. Banfield, after reviewing the conflict of interests between city and suburbs based on differences in race, national origin, social status, political party affiliation, religion and economic interests, finds that neither central city nor suburb is likely to give up the protection of its own local governments. Furthermore, he considers it valuable for the segregated pockets in a heterogeneous metropolis to be organized under separate local governments:

"[T]he organization which would be best for the management of conflict may not be best for area-wide planning and administration. Indeed, it may be that area-wide planning and administration would of necessity heighten conflicts by raising questions which can only be settled by bitter struggle.

"Conflict is not something to be avoided at all costs. It may be well, nevertheless, to consider if there are not decisive advantages in the organizational arrangements which now exist-arrangements which, while handicapping or entirely frustrating some important undertakings, also serve to insulate divergent interests and to protect them from each other. In view of their differences, it may be well, despite the obvious disadvantages, that the peoples of the central cities and of the suburbs live largely in separate political communities." 5

Robert C. Wood, on the other hand, starts with the proposition that debate and discussion should be encouraged. ${ }^{6}$ The major defect in the local government of metropolitan areas is, as he sees it, that conflicting interests have been so isolated within municipal boundary lines by the new segregation that there is "an absence of genuine political responsibility and an incapacity to make meaningful political decisions."

Both Wood and Banfield come essentially to the same conclusion about the kind of metropolitan organization that should be sought, at least in the immediate future. As Banfield puts it:

matic methods for regulating their relations with each other. Thus, the setting of the stage for international organization involves the development of the facts of division and interdependence in the external world, and of the moods of anxiety and dissatisfaction, coupled with hopeful determination and creative imagination, in the minds of men." ClaAdeE, op. cit. supra note 3, at 19.

5. Banfield, The Changing Politrcal Environment of City Planning 17 (paper delivered before the American Political Science Association, Washington, D.C., Sept. 6, 1956).

6. Wood, A Division of Powers in Metropolitan Areas (paper delivered before a joint meeting of the American Political Science Association and the Regional Science Association, Washington, D.C., Sept. 6, 1956). See also the paper delivered at the same meeting by Paul Ylvisaker. YLVISAKER, SOME CRITERIA FOR A "PROPER" AREAI. Division of GOVERnMENTAL Power (1956). 
"[A]rea-wide planning and administration should be attempted through the political structures that already exist. Rather than enter upon the probably futile and possibly dangerous course of creating new bodies by consolidation or federation it would be better in those places where fundamental cleavages exist to look to the political leaders of existing jurisdictions to negotiate among themselves settlements on the basis of which action may proceed. In effect this means that the political leaders of the central cities must be expected to come to terms with the political leaders of the states. For this to occur it is not necessary that both sets of leaders be of the same party, but it is necessary that both have power. In short, the metropolitan area problem will have to be solved-insofar as it is solved at all-by strong mayors and strong governors engaged in political give and take. Where special function districts are required their managers should be accountable to the voters, but not directly so, for this would entail the transfer of power from one electorate (and thus one party organization) to another something which is usually not feasible even if desirable. Instead, the people who run such districts should be accountable to a committee of mayors, county supervisors, governors who have a stake in the matter or to a committee of their appropriate subordinates. In this way accountability can be secured without the necessity of changing radically the distribution of political power. On this basis it should be possible to bring together administratively areas which are growing apart politically." 7

Wood also recommends "pragmatic innovations" instead of "grand designs or general systems":

"Adjustments in the responsibilities of existing levels of government, a host of cooperative arrangements, a tradition of intergovernmental collaboration can be used in breaking down the suburban repositories of Rousseau's general will and admitting some arrangements for pluralistic action. The solutions most scorned by experts, the "stop gap" "ad hoc" improvisions of functional cooperation, contractual services among local units, state grants-in-aid and shared taxes and joint planning efforts, take on new lustre. While these arrangements do not provide an orderly pyramid of functions, they do provide for different patterns for the exercise of power under processes of democratic control, since they bring together different groups of participants to debate and compromise. It is likely, as these experiments continue, that the present system of public officials negotiating for the jurisdictions involved may become regularized; that between state and local governments rational separations may appear, and that temporary arrangements may find formal expressions. Perhaps, the practicing politicians in local areas have made more progress than functional analysis implies, or than has been generally recognized." 8

7. BANFIELD, op. cit. supra note 5 , at 7 .

8. Wood, op. cit. supra note 6 , at 10 . 
It is clear from the discussion thus far that it is still useful to classify attempted and proposed governmental changes designed to meet metropolitan problems into those that will result in basic alterations of the jurisdiction, organization and activities of existing units of local government, and those that will leave at least their formal features largely undisturbed. It should be remembered that many of these devices can be and are being used at the same time in the same metropolitan area. ${ }^{9}$

The following methods involve few or no changes in the structural pattern of local government: (1) the grant of jurisdiction to the central city or large suburbs to provide services and to exercise controls outside their boundaries; (2) intergovernmental arrangements; (3) annexation of unincorporated territory; (4) the establishment of special districts and other types of $a d$ hoc authorities; (5) metropolitan planning; (6) the extension of state administration; and (7) the extension of federal administration.

Fundamental changes in jurisdiction, structure and function of existing units of local government would result from the use of one of the following approaches: (1) consolidation of adjacent municipalities; (2) city-county consolidation; (3) separation of the city from the county; (4) merging of special districts or authorities with either the central city or the county; (5) transformation of an area-wide special authority into a multi-functional government; (6) reorganization of the urban county and the transfer to it of metropolis-wide municipal functions; and (7) establishment of a "federated" or borough type of municipal government for the metropolitan area.

\section{Limited Structural Changes}

\section{Extraterritorial Services and Controls}

Extraterritorial services and controls are not important as a means of meeting the needs of, nor of relieving the pressure from, metropolitan government. Their use may lead to jurisdictional conflicts, bickering and hard feelings, rather than to cooperation between the governments of metropolitan areas. In California, municipalities have gone outside their boundaries to secure water, to build airports, and to

9. I shall, in this section, review the principal proposed or attempted solutions of the problems of governmental organization of metropolitan areas. Since I have twice before published such a review, I shall only attempt here to bring the descriptive summaries and my observations up to date. See Jones, Metropolitan Government cc. 45 (1942); Jones, Local Government Organization in Metropolitan Areas: Its Relation to Urban Redevelopment, in THE FUTURE, of CITIES AND URBAN REDEVELOPMENT 527 (Woodbury ed. 1953). 
dispose of sewage and other wastes. ${ }^{10}$ This power has undoubtedly eased the restrictive nature of municipal boundary lines.

\section{Intergovernmental Arrangements}

Intergovernmental arrangements are a spectrum ranging from the most informal personal understandings of public officials to the creation of joint agencies for the administration of particular programs. The least formal of intergovernmental arrangements arises out of the daily contacts of officials and other individuals interested in a problem. These contacts often are casual and lead to no action-unilateral, bilateral or multilateral. It is possible, however, to use conferences of people interested in common problems to raise intergovernmental issues and to communicate to each other the interests of the parties.

One of the difficulties is to find an acceptable convener. Suburban officials distrust the motives of the central city even in calling a conference; Republicans distrust Democrats, functional specialists distrust politicians, and vice versa.

The success of Mayor Wagner of New York City in allaying such suspicions has resulted in a formal metropolitan conference of county and municipal officials from the New York, New Jersey and Connecticut parts of the metropolitan area. Such matters as transit, water supply, traffic regulations and uniform regulations for the sale of liquor to minors have already been discussed and in some instances these discussions have led to changes in the policies of central city and suburbs.

A general assembly of local governments is not in itself a government. If this is understood, the editorial comment of the New York Times indicates the value of this type of arrangement:

"Our friends from beyond the city are reported eager and willing to talk. It is pretty hard to see how any harm could come of a metropolitan roundtable like this. On the other hand a great deal of good could come of it, through better acquaintance, exchange of information, frank airing of any grievances, criticisms and differences of opinions and, best of all, the fostering of a cordial cooperative approach to problems that cannot be solved by taking the small, the limited view. The meeting offers a fine opportunity, as the beginning of a continuing relationship." 11

In a few metropolitan areas, elaborate networks of metropolitan services and controls are being gradually built up through contracts for

10. Winston $W$. Crouch brings up to date his study of extraterritorial powers of cities. CROUCH, INTERGOVERNMENTAL RELATIONS 122-40 (Metropolitan Los Angeles: A Study in Integration vol. XV, 1954).

11. N.Y. Times, June 18, 1956, p. 24, col. 3. 
one unit of government to perform all or part of a function for another government. This device has been used most extensively in Los Angeles County; most municipalities in Los Angeles have entered into contracts for the performance by the county of one or more functions. ${ }^{22}$

Recently Los Angeles County has begun a new era of functional consolidation through intergovernmental arrangements. The so-called Lakewood Plan has led to the incorporation of a number of new municipalities that rely almost entirely upon the county, through contractual agreements, to provide municipal services. The city government becomes a tax-levying body, a negotiating agency and a grievance committee for its inhabitants. If the pattern spreads it could develop into a two-tier metropolitan government. Helen Jones thinks that it is the direction of the future development in Los Angeles:

"The continuation of this trend could eventually result in a metropolitan arrangement under which the cities would continue to administer purely local affairs but would have delegated to the county all major functions. Insofar as the relationship between the county and the cities is concerned, the end product would be closely akin to a system of metropolitan borough government." ${ }^{13}$

There must be a strong local government with which other units can make contracts. This could, of course, be the central city itself but probably the metropolitan county can work with suburban municipalities more easily than can the central city. ${ }^{14}$ Unfortunately few counties are organized to render such services.

The most formal intergovernmental arrangement is the creation of an ad hoc union of local governments. Some of these joint agencies are almost autonomous and are indistinguishable from special districts and authorities.

\section{Special Districts and Authorities}

Special districts and authorities are quite likely to constitute the metropolitan government of the future. They are not being formed as rapidly as some would wish, but the pressure for their creation is

12. For the extent of functional transfers to counties in California, see Bollens, The States and THE Metropolitan Problem 112 (1956).

13. Cottreli \& Jones, The Metropolis: Is Integration Possible? 106 (1955). This is volume 16 of a series entitled Metropolitan Los Angeles: A Study in Integration, published by the Haynes Foundation between 1952 and 1955 . The sixteen volumes are our best source of information and opinion about the pattern and operation of intergovernmental relations in a metropolitan community. agency.

14. Under the Atlanta Plan of Improvement, the city is the senior contracting 
steadily and persistently exerted by present or potential customers of the agency, often allied with technicians and professional people engaged in the activity. The logic of specialism leads to a special and independent agency of government for each special interest.

Special districts and authorities have many advantages over other metropolitan organizations: (1) their establishment does not extinguish the corporate existence of other units of government; (2) they may be used to straddle state boundary lines; (3) they may be used to circumvent constitutional and statutory debt and tax limits; and (4) they may be more easily organized to simulate the business corporation. Their advantages appear to be immediate and their disadvantages dim and in the future.

The great disadvantage of special districts and authorities lies in the cumulative effect of their use. One special district may be of no import, but ultimately their use will lead to functional disintegration. This is a problem of politics, of control, as well as of administration and will force us to reorder our values or start all over again to build a community from functional fragments.

The basic character of a special district or authority is changed if it is entrusted with several functions, among which scarce resources of money, personnel, time and energy must be allocated. If, therefore, special districts can be reorganized into a multi-functional district and the responsibility of the agency be broadened to a multi-interest public, the result, howsoever arrived at, is a general but limited metropolitan government.

County and municipal officials in the San Francisco Bay area appear to be conscious of this, and to be formulating general policies with respect to the organization of metropolitan special districts. They are attempting to have the governing board of each special district consist of an equal number of representatives from county boards of supervisors and from municipalities. In order to have one supervisor and one elected municipal official from each county, the latter is selected by a city selection commission consisting of all municipalities in the county. The Bay Area Air Pollution Control District is already organized in this way and efforts will be made in the coming session of the legislature to set up a Bay Area Transit District and a Regional Planning District in the same manner.

Local officials are, of course, anxious to retain control of metropolitan developments. They also realize the desirability of combining special districts into a general metropolitan district as soon as possible. A common organization of each special district would facilitate the merger. In fact, the same supervisor and elected municipal official 
could be designated to serve on each of the separate districts. Local officials are also aware that ultimately either representation or voting will have to be weighted in accordance with the population or the assessed valuation, or both, of the constituent units. And at least the chief executive should be elected at large by the metropolitan electorate. ${ }^{15}$

\section{Annexation}

Annexation of unincorporated territory, despite the widespread use of the method since 1945, will not bring into the central city enough of the fringe area to give it jurisdiction over the metropolis. ${ }^{16}$ Except for a few states, notably Virginia, Texas and Missouri (outside the St. Louis area), statutory and, at times, constitutional provisions make it difficult for a city to annex unincorporated territory and almost impossible to annex incorporated municipalities.

Annexation may be desirable in some instances even though some form of metropolitan government exists or is proposed. In some instances it may at the moment be the only course available to bring municipal services and regulations to fringe areas. It is highly desirable, therefore, that local and state annexation policies,. laws and practices be studied in the light of the objectives we wish to secure through local government. Such a study should be undertaken in each state by state and local officials and other interested groups.

\section{Metropolitan Planning}

It is sometimes claimed or intimated that metropolitan planning will make a more formal metropolitan government unnecessary because it will present guide lines that will motivate existing units of local government to cooperate with each other for the accomplishment of the regional goals. The claims are not false but exaggerated. Local government in metropolitan areas can be integrated only by an agency or agencies capable of legislative and administrative action on metropolitan problems. Planning, as the term is generally understood, should be part of that process. But disembodied planning is no substitute for government.

15. For further discussion, see Jones, Local Government Organization in Metropolitan Areas: Its Relation to Urban Redevelopment, in THE FUTURE OF CITIES AND URBAN REDEVELOPMENT 527, 573-86 (Woodbury ed. 1953) ; Bollens, THE STATES AND THE Metropolitan Problem 117-26 (1956) and his forthcoming book, Bollens, Special District Governments in the United States.

16. See the annual article on annexations by Bollens in the Municipal Year Book as well as his discussion in Bollens, The States and THE Metropolttan Probleim 25-52 (1956). 
The claims are in part correct because a well prepared and forcefully presented plan, even if dissociated in its making from a unit of government, may influence those in authority to whom it is communicated. Perhaps more important in the long run, the assemblage of data on the metropolitan community, the discussion of its economic and social unity and diversity, and the very existence of a metropolitan planning agency will increase the identification of individuals with the metropolitan community.

\section{Expansion of State Activities}

One way to secure the coordinated administration of a program is by the expansion of state activities. Over the past half-century, state functions have expanded and many of these have impinged directly upon the states' inhabitants who work and live in metropolitan areas. With the increasing density of population in the interstitial fringes between nearby metropolitan areas, which results in many urban problems extending into adjacent metropolitan areas and into adjacent states, we may expect both the state and national governments to become more directly involved in providing water, air and stream pollution controls and transportation. ${ }^{17}$

The report prepared by the Council of State Governments for the 1956 Conference of Governors is not concerned with the effect of metropolitanization on state services and regulatory activities. Certainly state officials need what John Bebout calls a "strategic sense of metropolitan relationships" in regulating public transportation, or in developing a water plan or public recreation program. This is all the more imperative since the future will probably see increasing commingling of federal, state and many kinds of local governments in almost every activity undertaken by governments.

The Council of State Government urges the states to accept the challenge of the national Commission on Intergovernmental Relations, and recommends that state governments "assume leadership in seeking solutions for the problems of metropolitan government."

"The states should assume three responsibilities in particular: (1) adoption of legal provisions authorizing the establishment of general metropolitan units; (2) appraisal of the adequacy of local governments; and (3) creation of continuing agencies to analyze and recommend on the needs and developments of metropolitan and non-metropolitan areas." 18

17. See Gulick, The Merropolitan Regions Look to THE State (paper delivered before the National Conference on Government, Memphis, Nov. 13, 1956).

18. Bollens, The States and the Metropolitan Probleim 132 (1956). 


\section{Extension of Federal Activities}

The extension of federal activities has occurred simultaneously with the rise of metropolitan communities and the expansion of state activities. Most urban problems are national problems. They become increasingly national as the proportion of the population living in metropolitan areas increases, and as the economic and social institutions of the nation become more complex and interdependent.

The result is that many federal agencies are now partners, some are senior partners, in the provision of services for, and in the regulation of, the activities of urban residents. The development of a strategic sense of metropolitanism, as well as of federal relations, is as imperative among federal as among state officials.

The report of the Commission on Intergovernmental Relations has placed the governmental and substantive problems of metropolitan areas in a context of national-state-local relations. ${ }^{19}$ Soon after the report was issued, the Conference of Governors acted to place the matter on their agenda. The result is the report of the Council of State Governments referred to above. Furthermore, through a special assistant to the President and the Bureat of the Budget, formal attention is being given in the federal government to the recommendations of the Commission.

Of course, everything said above about the responsibility of state governments can be repeated with respect to congressional responsibility for the interstate metropolitan area of Washington, D. C.

\section{Basic Structural Changes \\ Municipal Consolidation}

Consolidation of adjacent municipalities is almost impossible to accomplish. Even in the city-county consolidation proposed for Nashville and Davidson County, provision is made for incorporated suburbs to maintain their autonomy with respect to "urban services." 20 This is why annexation cannot be used to bring all or most of the metropolitan area under one government. Indeed, incorporation is often used as a defense against annexation.

19. Subcommittee on Intergovernmentax Relations of the House Committee on Governmental Operations, Staff Report on Replies From Federal Agencies to QuestronNaIRE on InTERgovernmental Relations (1956).

20. Nashville and Davidson County Planning Commissions, op. cit. supra note 2 , at 57 . 


\section{City-County Consolidation}

City-county consolidation was once the preferred method of achieving metropolitan government. Many unsuccessful proposals to consolidate city and county governments have been made, but the only successful attempt since Denver separated from the rural parts of Arapahoe County in 1909 was the consolidation of Baton Rouge and East Baton Rouge Parish in 1947. The latter is significant, not only because it was approved by the electorate, but because it provides for three tax and service areas: (1) an urban area consisting of the old city of 4.6 square miles and approximately twenty-five square miles of additional built-up territory; (2) two industrial areas where residences are forbidden and industries must provide their own services; and (3) the remainder of the parish as a rural area where municipal services can be rendered only if special taxing districts are created to finance them.

Every metropolitan plan should take account of the differences in need for municipal services in various parts of the area, of the fear of the suburban taxpayer that a metropolitan government will increase his tax burden, and of the reluctance of the city taxpayer to subsidize urban services to suburbanites through a county-wide tax. Under the proposed city-county consolidation in Nashville, there would be two service districts-one district covering the entire metropolitan area would receive all general services and the other covering the area of the old city of Nashville at the time of consolidation would, in addition, receive urban services. "The tax levy in the two service districts would be in direct ratio of the cost of the urban services to the cost of the general services, taking into consideration all sources of revenue and their application." 21

Except for 100 metropolitan areas lying wholly within one county, such as Baton Rouge, Birmingham and Nashville, city-county consolidation in its simple form is not possible. Furthermore, once the difficult act of consolidation has been accomplished, it will be doubly difficult, without the Virginia type of annexation procedures, to expand the area of the city-county.

\section{Separation}

Separation of the city from the county has been used by certain central cities recently as a threat with which to fight the payment of county taxes to provide urban services to people living in the unincor-

21. Id. at 39-42. See also CoOper, Metropolitan County: A SuRvey of GoverNMENT IN THE BIRMINGHAM AREA 144-45 (1949). 
porated fringe. It has none of the advantages and intensifies the disadvantages of city-county consolidation.

\section{Federation}

Federated forms of metropolitan government provide for a distribution of activities between a metropolitan government and constituent governments. If the constituent units are autonomous vis-à-vis the metropolitan government, with respect to the functions assigned to them, the characterization of such a two layer system of local government as "federal" is sufficiently descriptive of its advantages and of the main problems involved in establishing and maintaining it.

A "federal" type of metropolitan government can be secured (1) by creating a new "federal" government to replace existing units of government, (2) by transferring certain municipal functions to the county, and (3) by establishing a multi-purpose district or by transferring other functions to an existing special district. ${ }^{22}$ Metropolitan Toronto, the best example of a new federated metropolitan government in North America, is discussed in a separate paper in this symposium. ${ }^{23}$

A new area-wide government has been recommended for Seattle-a metropolitan municipal corporation of limited powers with counties, cities, towns and special districts continuing to perform all functions not assigned to the metropolitan government. The legislative body would be a council composed of representatives selected by the elected legislative officials "of the county, the central city and the smaller cities surrounding the central city and one member selected by this council, who is not an elected official of any component government, to serve as chairman." 24

Both the Miami and Pittsburgh proposals are built around a reorganized county government, to which would be assigned those functions and activities that, for whatever reason, are considered to be metropolitan. All other functions and activities, some to be exercised concurrently with the county, are retained by the existing municipalities.

Almost without exception, a county that assumes such metropolitan responsibilities needs to be reorganized in order to secure a representative legislative body and a responsible chief executive. ${ }^{25}$

22. These three types of general metropolitan government are recommended by the Council of State Governments. Bollenss, The Sitites and THE Merropolitan ProbLEM 132-36 (1956).

23. Milner, The Metropolitan Toronto Plan, 105 U. PA. L. REv. 570 (1957).

24. Munictpal League of Seattle and King County, Metropolitan Solution -The Shape of Things To Come (1956). See also 45 Nat'i Munic. Rev. 396 (1956).

25. See National Municipal League, Model County Cearier (1956), particularly the introduction by John Bebout. 
Under a home-rule amendment to the state constitution, metropolitan Miami is now drafting a metropolitan charter to be voted on next spring. ${ }^{28}$ Steps are now under way to place on the ballot an amendment to the Pennsylvania constitution that will enable metropolitan Pittsburgh to draft an urban home rule charter for Allegheny County. ${ }^{27}$

\section{Evaluation of Solutions for Metropolitan Problems}

The following propositions have been my guides in evaluating the principal ways that metropolitan communities have approached or propose to approach the problem of governing themselves:

(1). Metropolitan communities are growing so large and becoming so complicated that the effort to find solutions to their problems should be shared by federal, state and local governments.

(2). Whenever possible, a metropolitan government responsible to the inhabitants of the area is preferable to direct federal or state administration.

(3). It would be undesirable to attempt to govern the modern metropolis with its large area, huge population and many divergent interests as if it were a small, compact, homogeneous city.

(4). A metropolitan government should be devised that will provide effective services, guidance and controls where desired over the whole of the metropolitan area, that will equalize the burden of supporting such governmental functions, and that will facilitate effective citizen control of governmental policies which affect them at their places of work and recreation, as well as their places of residence.

(5). There should be an area-wide government with sufficient authority to make policy decisions about, and to administer, those matters that the community considers to be of metropolitan interest and concern.

(6). All or part of a governmental function might be assigned to a limited metropolitain government $(a)$ when co-ordination of a function over the whole area is essential to effective service or control in any part of the area; $(b)$ when it is desired to apply the ability-to-pay theory of taxation to the area as a whole, instead of allowing each part to support its own activities at whatever level its own economic base will permit; $(c)$ when services can be supplied more efficiently

\footnotetext{
26. See Public Administration Service, ThE Government of MEtropolitan Miami (1954).

27. See Metropolitan Study Commission of Allegheny County, An Urban Hode Rule Charter for Allegheny County (1955).
} 
through large-scale operations and when the advantages of large-scale operations are desired; and $(d)$ when it is necessary in order to assure citizens a voice in decisions that affect them in other parts of the metropolitan area, as well as the part in which they reside.

(7). There should be a net-work of sub-metropolitan governments, perhaps existing counties and municipalities, to legislate and administer those matters that the metropolitan community does not consider to require uniform treatment throughout the metropolitan area.

(8). The metropolitain government should be a general government with responsibility for enough functions so that it can weigh the claims of one function against those of other functions. Only a general government can, in planning and administering the government of a metropolis, take account of the delicate and intricate relations among governmental and private services and controls.

It may be said that all this is contrary to one of the lessons that we may learn from a study of international organization, namely, that there must be a community before there can be an effective and stable government. In the first place, the analogy between international organization and metropolitan organization is not watertight, for local governments are at law, and frequently in fact, creatures of all those political forces we call state governments. Furthermore, as Claude says, "There is evidently some truth in both the propositions that community creates government and that government creates community." 28

28. ClaUdE, op. cit. supra note 3 , at 416 . 